\title{
Diversity and distribution patterns of ants along elevational gradients
}

\author{
Indra Prasad Subedi ${ }^{1}$ (D) Prem Bahadur Budha ${ }^{1 *}$ (D) \\ ${ }^{1}$ Central Department of Zoology, Institute of Science and Technology, Tribhuvan University, Kirtipur, Nepal \\ *Correspondence: pbbudha@cdztu.edu.np
}

Received: 19 June 2020 | Revised: 28 July 2020 | Accepted: 29 July 2020

\begin{abstract}
Ants are one of the most successful groups of organisms present in almost all terrestrial habitats on the Earth. The published papers on ants with various sampling techniques were reviewed focusing on species richness along the elevational gradients to explain distribution patterns of ants and their potential drivers in the world. Pitfall trapping, hand collection, Winkler extractor and bait traps were found common sampling techniques for ant studies. Based upon literature, five broad distributional patterns were identified viz. mid-elevation peaks, decreasing, increasing, low plateaus, and constant patterns along the elevation ranging from 0 to $4800 \mathrm{~m}$ above sea level. The mid-elevation peak was a common pattern. However, ant species richness of Nepal follows a decreasing pattern based on the available records. Temperature was found as the major predictor of species richness patterns of ants.
\end{abstract}

Keywords: Altitudinal diversity, Formicidae, Mid-elevation, Species richness, Temperature

\section{1 | Introduction}

Ants (Family: Formicidae) are one of the most successful groups of organisms, present in all the terrestrial ecosystems of the earth. This group contains an estimated 30 percent of terrestrial animal biomass and more than 20,000 species (Holldobler \& Wilson 1990). Currently, there are 17 extant subfamilies, 337 genera and 13,806 species (Bolton 2020). Over $87 \%$ of the ant species described fall under four subfamilies viz. Myrmicinae, Formicinae, Ponerinae and Dolichoderinae (Guenard 2013). The oriental region has a peak of overall generic and endemic diversity of ants, most likely species diversity too (Guenard et al. 2012, Guenard 2013). The tropical countries contain the highest diversity of ants and species richness tends to decline both with increasing latitude and altitude (Guenard 2013). However, tropical regions of Africa were less diverse than the regions with similar latitude in Australasia or Neotropics (Guenard et al. 2012). Sanders (2002) observed a decreasing pattern with the maximum ant species richness at lowland habitats; however, others have reported maximum richness at mid-elevation habitats (Smith et al. 2014, Nowrouzi et al. 2016, Flores et al. 2018). A mid-elevation peak is the most typical $(50 \%)$ of altitudinal species richness pattern, but a decreasing pattern (25\%) has also been frequently reported (Rahbek 2005). The highest elevation record of an ant species (Formica picea lochmatteri Starke, 1935) is $4800 \mathrm{~m}$ in the Himalayas (Weber 1943). Whatever the case may be, the species richness in higher altitudes (above $1500 \mathrm{~m}$ ) tends to decline sharply with increasing altitude. Reasons for the decline in species richness at high altitude include increasingly unfavorable environments and the reduced available surface area, primary productivity and resource diversity (Lawton et al. 1987). Midelevation peaks may be described by the "ends are bad" and the "middle is good" processes (McCoy 1990). These processes highlight the roles of environmental constraints and the availability of resources upon the distributions of populations. The global ant elevational diversity patterns appear more complex than those of many vertebrate taxa, and they are further influenced by multiple drivers (Szewczyk \& McCain 2016). Flores et al. (2018) suggested that drought conditions at low elevations and cold temperatures at high elevations prevent the richness at both extremes of elevational gradients in the Mediterranean mountains. The key hypotheses to explain these broad-scale diversity gradients are based on temperature, water availability, productivity, area, geometric constraints and plant diversity (Peters et al. 2016).

Based on published records, there are 202 species of ants in the Himalayan region with $35 \%$ of them (71 species) which are 
endemic (Bharti 2008). The first comprehensive list of Nepalese ants by Collingwood (1970) listed 34 species collected from 830 $\mathrm{m}$ to $4550 \mathrm{~m}$ asl. In Nepal, altogether 127 nominal species of ants are known, however, the species number varies according to different publications (such as Antweb 2020, Thapa 2015, Collingwood 1970). An updated checklist and taxonomic status of known ant fauna of Nepal dealing with taxonomic inconsistencies and species distribution is under the preparation of the first author. Ant distribution patterns in Nepal are important due to Nepal's presence in the center of the Himalayas and it having the highest elevational gradient in the world. The elevational gradient studies on plant species of Nepal show the species richness increases up to $2500 \mathrm{~m}$ but the endemicity of narrow range vascular plants reach a peak around $4000 \mathrm{~m}$ (Vetaas \& Gryntes 2002).

This global-scale study is based on the selected literatures from different continents and available elevational records of Nepalese ant species showing the distributional patterns of ants along elevational gradients.

\section{2 | Methods}

The cited published papers were searched using keywords 'ant' with 'elevation', 'elevational', 'altitude', 'altitudinal', 'species richness' and 'diversity' using the Google scholar search engine.

These keywords were searched in the ScienceDaily for recent research news.

Furthermore, published original papers were also obtained from AntWeb, AntCat and AntWiki. Ant literature available in the English language, from 1943 to 2020, dealing with an elevation range up to $4800 \mathrm{~m}$ asl across the globe were reviewed. The reviewed papers include studies about areas spreading from the Equator to both the Northern and Southern hemispheres. The majority of these papers, nevertheless, dealt with the Northern hemisphere. Based on the review of papers on ant distribution patterns, survey methods used and the drivers of ant diversity (if noted) were highlighted. For depicting the ant species richness pattern in Nepal, the available elevational records of Nepalese ants were used.
Table 1. Diversity patterns of ants and survey methods in elevational gradient studies

\begin{tabular}{|c|c|c|c|c|}
\hline Diversity pattern & Study site/s & $\begin{array}{l}\text { Altitudinal } \\
\text { range (m) }\end{array}$ & Survey method/s & Reference \\
\hline \multirow{13}{*}{$\begin{array}{l}\text { Mid Elevation } \\
\text { Peak (MEP) }\end{array}$} & Panama & $300-2020$ & WE, PT & Olson 1994 \\
\hline & Philippines & $250-750$ & PT, HC & Samson et al. 1997 \\
\hline & Madagascar & $400-1950$ & LS, PT & Fisher 1998 \\
\hline & South Africa & $0-2000$ & PT & Botes et al. 2006 \\
\hline & USA & $594-1673$ & WE, MT, PT & Lessard et al. 2007 \\
\hline & India & $300-1650$ & WE, BTF & Sabu et al. 2008 \\
\hline & India & $500-4000$ & PT, LS, SB, SC, BT, HC & Bharti et al. 2013 \\
\hline & Southern Africa & $900-3000$ & PT & Bishop et al. 2014 \\
\hline & North Western Costa Rica & $7-1500$ & PT, WE, BT, HC, MT & Smith et al. 2014 \\
\hline & Australia & $100-1,300$ & BT, WE & Nowrouzi et al. 2016 \\
\hline & Central Spain & $685-2390$ & PT & Flores et al. 2018 \\
\hline & Costa Rica to Mexico & $20-2600$ & BT, S, SB & Longino et al. 2019 \\
\hline & Panama and Costa Rica & $30-2600$ & WE & Longino and Branstetter 2019 \\
\hline \multirow{9}{*}{$\begin{array}{l}\text { Decreasing with } \\
\text { Elevation (DWE) }\end{array}$} & Eastern Madagascar & $785-1680$ & WE, PT, HC & Fisher 1996 \\
\hline & USA & $379-1742$ & WE & Sanders et al. 2007 \\
\hline & Borneo & $580-1520$ & WE, GS & Malsch et al. 2008 \\
\hline & Montenegro & $100-1900$ & $\mathrm{HC}$ & Karamen 2011 \\
\hline & USA and Australia & $350-3000$ & Literature & Machac et al. 2011 \\
\hline & Australia & $300-1100$ & $\mathrm{LS}, \mathrm{BF}, \mathrm{HC}$ & Burwell and Nakamura 2011 \\
\hline & Malaysia & $300-1100$ & PT & Yusah et al. 2012 \\
\hline & Andorra and France & $1000-2300$ & PT, HC & Bernadou et al. 2013 \\
\hline & Eastern Himalaya & $600-2400$ & PT, WE & Marathe et al. 2020 \\
\hline \multirow[t]{2}{*}{ Low Plateau (LP) } & Southeastern Brazil & $800-1500$ & $\mathrm{BT}, \mathrm{HC}$ & Araujo and Fernandes 2003 \\
\hline & Austria & $400-3312$ & MR & Glaser 2006 \\
\hline $\begin{array}{l}\text { Increasing with } \\
\text { Elevation (IWE) }\end{array}$ & Venezuela & $70-598$ & PT, HC & Perez-Sanchez et al. 2013 \\
\hline \multirow[t]{2}{*}{ Constant } & Gabon & $110-640$ & LS, SB, YPT, PT, MT, HC & Fisher 2004 \\
\hline & Egypt & $90-1730$ & PT & Orabi et al. 2011 \\
\hline MEP and LP & Costa Rica & $50-2000$ & WE & Longino and Colwell 2011 \\
\hline IWE and MEP & U.S.A. & $900-2500$ & PT & Sanders et al. 2003 \\
\hline \multirow[t]{2}{*}{ MEP and DWE } & Tanzania & $860-4390$ & SBE & Peters et al. 2014 \\
\hline & China & $800-3200$ & PT, GS, MT, BF, BTF & Fontanilla et al. 2019 \\
\hline - & Eastern Switzerland & $1800-2550$ & $\mathrm{HC}, \mathrm{PT}$ & Reymond et al. 2013 \\
\hline - & South Korea & $800-1577$ & PT, BT & Kwon 2016 \\
\hline
\end{tabular}

Survey methods (BT: bait traps; BF: canopy or bark fogging; HC: hand collection; LS: litter sifting; MT: malaise traps; PT: pitfall traps; MR: museum records; WE: Winkler extractor; S: sweeping; YPT: yellow pan traps; BTF: Burlese-Tullgren funnel; SB: stick beating; SBE: standardized bait experiment, SC: soil cores, GS: general search) 


\section{3 | Results and discussion}

\section{1 | Ant distribution patterns along elevation gradients}

Global diversity and distribution patterns of ants are yet to be well-understood. In general, five broad patterns of ant elevational diversity were recorded from selected literatures:

i. Decreasing patterns (the highest diversity in the lowest elevation)

ii. Low plateaus (high diversity across the lowest elevation up to $300 \mathrm{~m}$ ),

iii. Mid-elevation peaks (highest diversity at middle elevations above $300 \mathrm{~m}$ from the base),

iv. Increasing patterns (increasing diversity with increasing elevation), and

v. Constant (none of the above definitions).

Diversity patterns of ants and survey methods used in selected elevational gradient studies have been summarized in the Table 1. Studies have shown that out of the five patterns of ant diversity along elevation gradients, the two commonest patterns were the mid-elevation peak and decreasing patterns. The mid-elevation peak pattern was most common with nearly $51 \%$ of the studies ranging up to $4000 \mathrm{~m}$ - followed by a decreasing pattern with nearly $33 \%$ of the studies - ranging from $100 \mathrm{~m}$ to $4390 \mathrm{~m}$ (Table 1). Higher species richness at mid-elevations is because of climatic severity in the higher or lower elevations and the availability of limited resources at higher elevations (McCoy 1990). Generally, low elevations are too hot except for winters and higher elevations are too cold or frigid throughout. The highest productivity at mid-elevations is due to the presence of higher photosynthetic and lower respiratory rates (Janzen 1973) which results in the hump-shaped pattern of species distribution. Species richness decline monotonically with increasing altitude because of reduced temperature and consequent decreased productivity which is often thought to reflect the latitudinal gradient (Rahbek 1995, 1997). However, the patterns of species richness may be different within or between taxa at low and mid-elevations and also between different regions or within areas on a regional scale (Rahbek 1995)

Species richness was the highest at the lowest elevation of the southern slope and again at the mid-elevation of the northern slope of Soutpansberg Mountain, South Africa (Munyai \& Foord 2012). Peters et al. (2014) observed species richness at a midelevation peak in managed ecosystems while a decline with elevation was seen in natural ecosystems. Sanders et al. (2003) suggested that species richness for some taxa may be the highest even at high altitudes in arid ecosystems. In such ecosystems, lower temperature and higher precipitation may support higher primary productivity and cause low levels of physiological stress. Variations in diversity patterns may also be dependent upon the sampling and scale of the study. However, no specific trends in species distribution have been identified either continent-wise or the hemisphere-wise.

Available elevational records of Nepalese ants from $200 \mathrm{~m}$ to $4550 \mathrm{~m}$ were used to extrapolate the species richness pattern along an altitudinal gradient in Nepal (AntWeb 2020, Thapa 2015, Collingwood 1970). The data showed that the species richness of Nepalese ants follows a decreasing pattern (Figure 1). However, most of the areas of Nepal are still unexplored and it is difficult to generalize ant distribution patterns with the few collections and limited published information on Nepalese ant species.

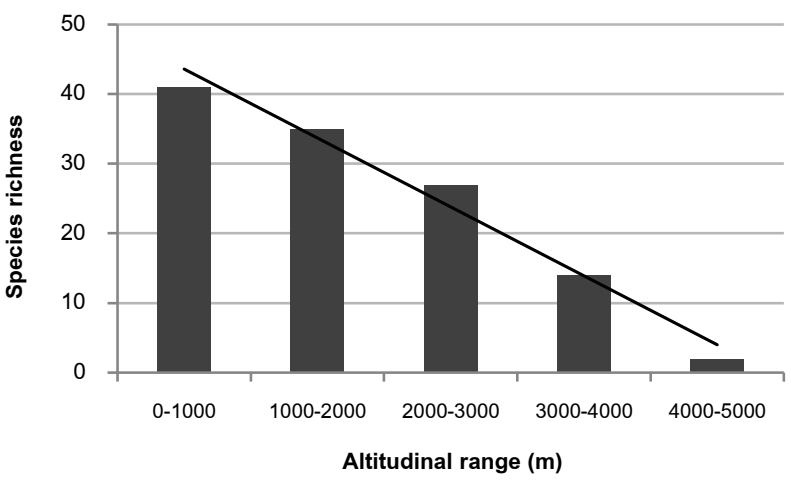

Figure 1. Ant species richness pattern along altitude in Nepal ( $N=83$ species) $\left(y=-9.9 x+53.5, R^{2}=0.9774\right)$

The ant surveys representing most of the sampling techniques viz. pitfall traps, Winkler extractor (litter sifting), bait traps, hand collection, canopy or bark fogging, malaise traps, sweeping, yellow pan traps, Burlese-Tullgren funnel, stick beating and soil cores were used for assessing the ant species richness along elevation gradients (Table 1). The most frequently used survey method in the ant inventory was the pitfall trap method followed by litter sifting and Winkler extractor, hand collection, and the bait traps. The majority of the studies used two or more methods for the collection of ants while some studies used a single method viz. pitfall trap or Winkler extractor. It is more or less obvious that use of multiple methods are likely to produce better results. 


\section{2 | Drivers of ant diversity}

Temperature has been described as a prominent driver (Bernadou et al. 2013, Sanders et al. 2007, Malsch et al. 2008) or the most important predictor (Longino \& Colwell 2011, Bishop et al. 2014, Machac et al. 2011) of species richness. Relative humidity, soil nutrients, elevation-specific regional area, and the mid-domain effects were reported to have comparatively less impact on ant species richness (Longino \& Colwell 2011). Species richness is also influenced by different sets of variables among the individual taxonomic groups but temperature is the most important in the majority of taxa (Peters et al. 2016). Marathe et al. (2020) suggested that elevational richness patterns are driven by a combination of climatic and geometric constraints. Variation in ant species richness over the elevational gradient was partially explained by climate (Sanders et al. 2003) and was influenced by the presence of favourable physical conditions and the prey resources (Sabu et al. 2008). Decline in species richness is correlated with decreasing temperature, high humidity, scarcity of nesting places and nutritional resources (Malsch et al. 2008). Local habitat features like sun exposure, vegetation density, surface moisture (Bernadou et al. 2013, Munyai \& Foord 2012, Araujo \& Fernandes 2003), vegetation types (Lasmar et al. 2020), types and number of nutrients (Peters et al. 2014) and available areas (Bishop et al. 2014) also influence species diversity. Elevation influences the changes in ant communities often due to increased moisture availability (MontBlanc et al. 2007).

\section{4 | Conclusions}

The review concludes the mid-elevation peak as a common species richness pattern followed by a decreasing pattern. Other patterns include increasing pattern, low plateaus and constant. The majority of the studies reported temperature as the important driver of diversity. Pitfall traps, Winkler extractors, hand collection and bait traps are found common ant survey methods. Based upon available elevational records, the species richness of Nepalese ants shows a decreasing pattern. Further systematic surveys and inventories of unexplored areas representing wide elevation range can provide the picture of real distribution pattern of ant species in Nepal.

\section{Acknowledgements}

We thank the anonymous reviewers and the journal editors for their insightful comments and suggestions.

\section{Authors' contributions}

Subedi, I. P. conceived the study and analyzed the data; both authors wrote the manuscript

\section{Conflicts of interest}

Authors declare no conflict of interest.

\section{ORCID}

Indra Prasad Subedi iD https://orcid.org/0000-0003-3385-2018

Prem Bahadur Budha iDhttps://orcid.org/0000-0003-0205-0979

\section{References}

Araujo, L.M. and Fernandes, G. W. 2003. Altitudinal patterns in a tropical ant assemblage and variation in species richness between habitats. Lundiana 4(2):103-109.

AntWeb 2020. California Academy of Science. https://www.antweb.org/country.do?name=Nepal. Accessed on 27 July 2020.

Bernadou, A., Cereghino, R., Barcet, H., Combe, M., Espadler, X. and Fourcassie, V. 2013. Physical and land-cover variables influence ant functional groups and species diversity along elevational gradients. Landscape Ecology 28(7):1387-1400.

Bharti, H. 2008. Altitudinal Diversity of Ants in Himalayan Regions (Hymenoptera: Formicidae). Sociobiology 52(2):305-322.

Bharti, H., Sharma, Y. P., Bharti, M. and Pfeiffer, M. 2013. Ant species richness, endemicity and functional groups, along an elevational gradient in the Himalayas. Asian Myrmecology 5:79-101.

Bishop, T. R., Robertson, M. P., Rensburg, B. J. V. and Parr, C. L. 2014. Elevation-diversity patterns through space and time: ant communities of the Maloti-Drakensberg Mountains of southern Africa. Journal of Biogeography 41:2256-2268.

Bolton, B. 2020. An Online Catalog of the Ants of the World, http://www.antcat.org, Accessed on 26 July 2020.

Botes, A., McGeoch, M. A., Robertson, H. G., Niekerk, A. V., Davids, H. P. and Chown, S. L. 2006. Ants, altitude and change in the northern Cape Floristic Region. Journal of Biogeography 33:7190.

Burwell, C. J. and Nakamura, A. 2011. Distribution of ant species along an altitudinal transect in continuous rainforest in subtropical Queensland, Australia. Memoirs of the Queensland Museum Nature 55(2):391-411.

Collingwood, C. A. 1970. Formicidae (Hymenoptera: Aculeata) from Nepal. Khumbu Himal 3(3):371-387. 
Fisher, B. L. 1996. Ant diversity patterns along an elevational gradient in the Réserve Naturelle Intégrale d'Andringitra, Madagascar. Fieldiana Zoology 85:93-108.

Fisher, B. L. 1998. Ant diversity patterns along an elevational gradient in the Reserve Speciale d'Anjanaharibe- Sud and on the western Masoala Penninsula, Madagascar. Fieldiana Zoology 90:39-67.

Fisher, B. L. 2004. Diversity patterns of ants (Hymenoptera: Formicidae) along an elevational gradient on Monts Doudou in Southwestern Gabon. California Academy of Sciences Memoir 28:269-286.

Flores, O., Seoane, J., Hevia, V. and Azcarate, F. M. 2018. Spatial patterns of species richness and nestedness in ant assemblages along an elevational gradient in a Mediterranean mountain range. PLoS ONE 13:e0204787. https://doi.org/10.1371/journal.pone. 0204787

Fontanilla, A. M., Nakamura, A., Xu, Z., Cao, M., Kitching, R. L., Tang, Y. et al. 2019. Taxonomic and functional ant diversity along tropical, subtropical, and subalpine elevational transects in Southwest China. Insects 10:128. https://doi.org/10.3390/insects 10050128

Glaser, F. 2006. Biogeography, diversity and vertical distribution of ants (Hymenoptera: Formicidae) in Vorarlberg, Austria. Myrmecological News 8:263-270.

Guenard, B. 2013. An overview of the Species and Ecological Diversity of ants. In: eLS. John Wiley and Sons, Ltd: Chichester. https://doi.org/10.1002/9780470015902.a0023598

Guenard, B., Weiser, M. D. and Dunn, R. R. 2012. Global models of ant diversity suggest regions where new discoveries are most likely are under disproportionate deforestation threat. Proceedings of the National Academy of Sciences of the USA 109(19):7368-7373.

Holldobler, B. and Wilson, E. O. 1990. The ant. Cambridge, Mass: Harvard University Press, xii+732pp.

Janzen, D. H. 1973. Sweep samples of tropical foliage insects: effects of seasons, vegetation types, elevation, time of day, and insularity. Ecology 54:687-708.

Karaman, M. G. 2011. Zoogeography, diversity and altitudinal distribution of ants (Hymenoptera: Formicidae) in the Mediterranean and the oro-Mediterranean parts of Montenegro. North-Western Journal of Zoology 7(1):26-34.

Kwon, T. S. 2016. Foraging activity of competing ants along altitudinal gradient on a high mountain, South Korea. Journal of AsiaPacific Entomology 19:95-101.

Lasmar, C. J., Ribas, C. R., Louzada, J., Queiroz, A. C. M., Feitosa, R. M., Imata, M. M. G. et al. 2020. Disentangling elevational and vegetational effects on ant diversity patterns. Acta Oecologica 102:103489.
Lawton, J. H., MacGarvin, M. and Heads, P. A. 1987. Effects of altitude on the abundance and species richness of insect herbivores on bracken. Journal of Animal Ecology 56:147-160.

Lessard, J. P., Dunn, R. R., Parker, C. R. and Sanders, N. J. 2007. Rarity and diversity in forest ant assemblages of Great Smoky Mountains National Park. Southeastern Naturalist 6:215-228.

Longino, J. T. and Branstetter, M. G. 2019. The truncated bell: an enigmatic but pervasive elevational diversity pattern in Middle American ants. Ecography 42: 272-283. https://doi.org/10.1111/ecog.03871

Longino, J. T. and Colwell, R. K. 2011. Density compensation, species composition, and richness of ants on a neotropical elevational gradient. Ecosphere 2(3):art29. https://doi.org/10.1890/ES10-00200.1

Longino, J. T., Branstetter, M. G. and Ward, P. S. 2019. Ant diversity patterns across tropical elevation gradients: effects of sampling method and subcommunity. Ecosphere 10(8):e02798. https://doi.org/10.1002/ecs2.2798

Machac, A., Janda, M., Dunn, R. R. and Sanders, N. J. 2011. Elevational gradients in phylogenetic structure of ant communities reveal the interplay of biotic and abiotic constraints on diversity. Ecography 34:364-371.

Malsch, A. K. F., Fiala, B., Maschwitz, U., Mohamed, M., Nais, J. and Linsenmair, E. 2008. An analysis of declining ant species richness with increasing elevation at Mount Kinabalu, Sabah, Borneo. Asian Myrmecology 2:33-49.

Marathe, A., Priyadarsanan, D. R., Krishnaswamy, J. and Shanker, K. 2020. Spatial and climatic variables independently drive elevational gradients in ant species richness in the Eastern Himalaya. PLoS ONE 15(1):e0227628. https://doi.org/10.1371/journal.pone.0227628

McCoy, E. D. 1990. The distribution of insects along elevational gradients. Oikos 58:313-332.

MontBlanc, E. M., Chambers, J. C. and Brussard, P. F. 2007. Variation in ant populations with elevation, tree cover, and fire in a pinyonjuniper-dominated watershed. West North American Naturalist 67:469-491.

Munyai T. C. and Foord S. H. 2012. Ants on a mountain: spatial, environmental and habitat associations along an altitudinal transect in a centre of endemism. Journal of Insect Conservation 16:677-695. https://doi.org/10.1007/s10841-011-9449-9

Nowrouzi, S., Andersen, A. N., Macfadyen, S., Staunton, K. M., VanDerWal, J. and Robson, S. K. A. 2016. Ant Diversity and Distribution along Elevation Gradients in the Australian Wet Tropics: The Importance of Seasonal Moisture Stability, PLoS ONE 11(4):e0153420. https://doi.org/10.1371/journal.pone.0153420 
Olson, D., 1994. The distribution of leaf litter invertebrates along a Neotropical altitudinal gradient. Journal of Tropical Ecology 10(2):129-150

Orabi, G. M., Semida, F. M., Abdel-Dayem, M. S., Sharaf, M. R. and Zalat, S.M. 2011. Diversity patterns of ants along an elevation gradient at St. Catherine Protectorate, South Sinai, Egypt (Hymenoptera: Formicidae). Zoology in the Middle East 54:101112.

Perez-Sanchez, A. J., Lattke, J. E. and Viloria, A. L. 2013. Patterns of ant (Hymenoptera: Formicidae) richness and relative abundance along an aridity gradient in Western Venezuela. Neotropical Entomology 42:128-136.

Peters, M. K., Andreas H, Appelhans, T., Behler, C., Classen, A., Detsch, F. et al. 2016. Predictors of elevational biodiversity gradients change from single taxa to the multi-taxa community level. Nature Communications. 7:13736. https://doi.org/10.1038/ncomms13736.

Peters, M. K., Mayr, A., Roder, J., Sanders, N. J. and SteffanDewenter, I. 2014. Variation in nutrient use in ant assemblages along an extensive elevational gradient on Mt Kilimanjaro. Journal of Biogeography 41:2245-2255

Rahbek, C. 1995. The elevational gradient of species richness: A uniform pattern? Ecography 18(2):200-205.

Rahbek, C. 1997. The relationship among area, elevation, and regional species richness in neotropical birds. The American Naturalist 149(5):875-902. https://doi.org/10.1086/286028

Rahbek, C. 2005. The role of spatial scale and the perception of largescale species-richness patterns. Ecology Letters 8: 224-239

Reymond, A., Purcell, J., Cherix, D., Guisan, A. and Pellissier, L. 2013. Functional diversity decreases with temperature in high elevation ant fauna. Ecological Entomology 38:364-373. https://doi.org/10.1111/een. 12027

Sabu, T., Vineesh, P. and Vinod, K. V. 2008. Diversity of forest litterinhabiting ants along elevations in the Wayanad region of the Western Ghats. Journal of Insect Science 8:69-83.

Samson, D. A., Rickart, E. A. and Gonzales, P. C. 1997. Ant diversity and abundance along an elevational gradient in the Philippines. Biotropica 29:349-363.

Sanders, N. J. 2002. Elevational gradients in ant species richness: area, geometry, and Rapoport's rule. Ecography 25:25-32. https://doi.org/10.1034/j.1600-0587.2002.250104.x

Sanders, N. J., Lessard, J. P., Fitzpatrick, M. C. and Dunn, R. R. 2007. Temperature but not productivity or geometry, predicts elevational diversity gradients in ants across spatial grains. Global Ecology and Biogeography 16:640-649.
Sanders, N. J., Moss, J. and Wagner, D. 2003. Patterns of ant species richness along elevational gradients in an arid ecosystem. Global Ecology and Biogeography 12:93-102. https://doi.org/10.1046/j. 1466-822X.2003.00324.x

Smith, M. A., Hallwachs, W. and Janzen, D. H. 2014. Diversity and phylogenetic community structure of ants along a Costa Rican elevational gradient. Ecography 37:720-731.

Szewczyk, T. and McCain, C. M. 2016. A systematic review of global drivers of ant elevational diversity. PLoS ONE 11(5):e0155404. https://doi.org/10.1371/journal.pone.0155404

Thapa, V. K. 2015. Insect diversity in Nepal. Format Printing Press, Kathmandu, p 1097.

Vetaas, O. R. and Grytnes, J. A. 2002. Distribution of vascular plant species richness and endemic richness along the Himalayan elevation gradient in Nepal. Global Ecology and Biogeography 11:291-301.

Weber, N. A. 1943. The ants of the Imatong Mountains, Anglo-Egyptian Sudan. Bulletin of Museum of Comparative Zoology, Harvard College 93:263-289.

Yusah, K. M., Turner, E. C., Yaha, B. E. and Maurice, T. 2012. An elevational gradient in litter-dwelling ant communities in Imbak Canyon, sabah, Malaysia. Journal of Tropical Biology and Conservation 9(2):192-199.

\section{Cite this article as:}

Subedi, I. P. and Budha, P. B. 2020. Diversity and distribution patterns of ants along elevational gradients. Nepalese Journal of Zoology 4(1):44-49. https://doi.org/10.3126/njz.v4i1.30672 